\title{
Siew New Disease Reports \\ First report of Tomato leaf curl virus and Croton yellow vein mosaic betasatellite infecting chilli plants in Pakistan
}

\author{
S. Yasmin ${ }^{1 *}$, S. Hameed ${ }^{2}$, N.I. Raja ${ }^{1}$ and J.K. Brown ${ }^{3}$ \\ ${ }^{1}$ Pir Mehr Ali Shah Arid Agriculture University, Shamsabad, Muree Road, Rawalpindi, 46000, Pakistan; ${ }^{2}$ National \\ Agriculture Research Centre, Islamabad, Pakistan; ${ }^{3}$ School of Plant Sciences, The University of Arizona, Tucson, AZ 85721 \\ USA
}

*E-mail: samyasmin@ymail.com

Published: 27 Feb 2018.

Leaf curl disease poses a major constraint to chilli (Capsicum апnиит) production in Pakistan. In October 2014, chilli plants exhibiting geminivirus-like symptoms, including leaf curling and stunting were observed at the National Agriculture Research Centre (Islamabad, Pakistan), with an incidence of 50\%. Leaf samples were collected from ten diseased chilli plants. The samples were tested by TAS-ELISA using a panel of ten monoclonal antibodies (Harrison et al., 1997). A total of eight monoclonal antibodies indicated the presence of begomoviruses in five field samples.

Total plant DNA was purified from leaf tissue using the DNeasy Plant Minikit (Qiagen, USA). A degenerate primer pair (Yasmin et al., 2017), designed to amplify a fragment of approx. $650 \mathrm{bp}$ from the coat protein gene of the genome or DNA-A component of begomoviruses, was used in PCR. Five amplified fragments were cloned and sequenced. A BLASTn search indicated the presence of a begomovirus most closely related to Tomato leaf curl virus (ToLCV-[NP:Pan:00]; GenBank Accession No. AY234383), with $99.0 \%$ nucleotide sequence identity.

To enrich circular viral DNA, rolling circle amplification was done using total nucleic acid extract as template with an IllustraTempliPhi 500 amplification kit (GE Healthcare, USA). The product from one plant sample was digested with HindIII, cloned into the plasmid vector pGEM3Z (Promega, USA) and sequenced. Pairwise nucleotide sequence comparisons using the Sequence Demarcation Tool (SDT v1.2) (Muhire et al., 2014) indicated that the chilli isolate was most closely related to ToLCV-[NP Pan:00], with $99.2 \%$ nt identity. This indicates that the virus in chilli is an isolate of ToLCV for which the isolate descriptor ToLCV-[Pakistan: Islamabad: chilli; 2014]-(KY799159) is proposed. The presence of a betasatellite in the plant from which the virus was cloned, was confirmed by PCR amplification using the betasatellite-specific primer pair F-5/R-5 (Yasmin et al., 2017). One amplified betasatellite genome was cloned in pGEM3Z and sequenced. SDT analysis showed the highest level of identity (93.4\%) with Croton yellow vein mosaic betasatellite (CroYVMB; HM143903). This showed the betasatellite associated with ToLCV to be an isolate of CroYVMB, for which the isolate descriptor
CroYVMB-[Pakistan: Islamabad: chilli; 2014](KY769276) is proposed. In India ToLCV is a widespread and important pathogen of tomato (Jyothsna et al., 2013; Ranjan et al., 2014).This is the first report of the association of ToLCV and CroYVMB with chilli plants exhibiting leaf curl symptoms in Pakistan.

\section{Acknowledgements}

The first author extends her profound gratitude to the Higher Education Commission (HEC), Pakistan for financial support and the National Agriculture Research Centre, Pakistan, the University of Arizona, USA for hosting her as an HEC Fellow, and members of Professor Brown's laboratory for helpful suggestions, guidance and technical support.

\section{References}

Harrison BD, Liu YL, Khalid S, Hameed S, Otim-Nape GW, Robinson DJ, 1997. Detection and relationships of cotton leaf curl virus and allied whitefly-transmitted geminiviruses occurring in Pakistan. Annals of Applied Biology 130, 61-75.

http://dx.doi.org/10.1111/j.1744-7348.1997.tb05783.x

Jyothsna P, Rawat R, Malath VG, 2013.Predominance of tomato leaf curl Gujarat virus as a monopartite begomovirus: associated with tomato yellow leaf curl Thailand betasatellite. Archives of Virology 158, 217-224. http://dx.doi.org/10.1007/s00705-012-1468-7

Muhire BM, Varsani A, Martin DP, 2014. SDT: A virus classification tool based on pairwise sequence alignment and identity calculation. PLoS One $\mathbf{9}$ e108277. http://dx.doi.org/10.1371/journal.pone.0108277

Ranjan P, Kumar RV, Chakraborty S, 2013. Differential pathogenicity among Tomato leaf curl Gujarat virus isolates from India. Virus Genes 47, 524-531. http://dx.doi.org/10.1007/s11262-013-0977-0

Yasmin S, Raja NI, Hameed S, Brown JK, 2017. First association of Pedilanthus leaf curl virus, Papaya leaf curl virus, Cotton leaf curl Kokharan virus, and Papaya leaf curl betasatellite associated with symptomatic chilli pepper in Pakistan. Plant Disease 101, 2155. http://dx.doi.org/10.1094/PDIS-06-17-0883-PDN

Figure 1

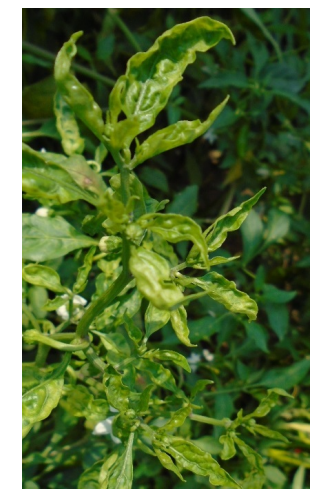

To cite this report: Yasmin S, Hameed S, Raja NI, Brown JK, 2018. First report of Tomato leaf curl virus and Croton yellow vein mosaic betasatellite infecting chilli plants in Pakistan. New Disease Reports 37, 10. http://dx.doi.org/10.5197/j.2044-0588.2018.037.010 (c) 2018 The Authors

This report was published on-line at www.ndrs.org.uk where high quality versions of the figures can be found. 